\title{
Comparison of the Spreading Characters of Fire Products in the Typical Metro Stations of Washington, D.C., and Guangzhou
}

\author{
Heng $\mathbf{Y u}^{1,2}$ (D)
}

Received: 31 March 2021/Revised: 25 October 2021/Accepted: 27 October 2021/Published online: 17 November 2021

(C) The Author(s) 2021

\begin{abstract}
Fire is one of the most common disasters that threaten the safety of the crowd in metro stations. Due to the variations in the design of metro stations, the hazard posed by the spreading products of the fire can pose different risks. The typical structures of metro stations in Guangzhou and Washington, D.C., are very different from each other. In Washington, D.C., the "high-dome" structure is predominant in the construction of metro stations, while in Guangzhou, most metro stations have the "flat ceiling" structure. In this article, a numerical modeling for fire dynamic simulation is used to predict and compare the spreading characters of fire products (the smoke height change, the temperature distribution and the visibility change) when fires with $2.5 \mathrm{MW}$ heat release rate occur in the platform center and at the platform end in the two kinds of metro stations. The results show that, in the same fire scenario, the lowest smoke heights monitored in the Guangzhou model is $0.6 \mathrm{~m}$ (fire at the platform end) and $0.8 \mathrm{~m}$ (fire in the platform center) above the safe smoke height in $360 \mathrm{~s}$ after a fire breaks out, while it is $6.15 \mathrm{~m}$ (fire in the platform center) and $6.2 \mathrm{~m}$ (fire at the platform end) above the smoke height in the Washington model. The temperature increment in the Guangzhou model is $23{ }^{\circ} \mathrm{C}$ (fire in the platform center) to $29^{\circ} \mathrm{C}$ (fire at the platform
\end{abstract}

Heng Yu

hengyu126@yahoo.com

1 School of Architecture and Civil Engineering, Chengdu University, 2025 Cheng Luo Ave, Chengdu, Sichuan Province, China

2 School of Civil Engineering, Southwest Jiaotong University, No. 111 Bei Duan, Second Ring Road, Chengdu, Sichuan Province, China

Communicated by Zijia Wang. end) in $360 \mathrm{~s}$ after the fire breaks out, while the temperature increment in the same period in the Washington model is $8.5^{\circ} \mathrm{C}$ (fire at the platform end) to $9{ }^{\circ} \mathrm{C}$ (fire in the platform center). The visibility of most areas on the platform of the Guangzhou model is about $1 \mathrm{~m}$ no matter the fire is in the platform center or at the platform end at $360 \mathrm{~s}$ after the fire begins, while in the Washington model, the visibility of most areas is $1.5-13.5 \mathrm{~mm}$ (fire at the platform end) to 4-14 $\mathrm{m}$ (fire in the platform center) at the same moment. Based on the results, the environment is worse when the fire happens at the end of the platform than that when the fire happens in the platform center of the Guangzhou model. While the fire location has fewer impacts on the smoke height, temperature, and visibility in the Washington model, metro stations with a high-dome structure can be beneficial to fire evacuation safety; however, the construction cost can be high. Metro stations with flat ceiling are widely used in more cities for it has lower construction cost; to compensate for its weaker abilities under fire conditions, it is suggested that smoke exhaust systems should be carefully and fully considered.

Keywords Metro station - Fire dynamic simulation - Fire products $\cdot$ Spreading characters $\cdot$ Smoke spread .

Numerical modeling

\section{Introduction}

With rapid urbanization, more and more urban rail transit systems are under construction or in planning; this phenomenon is especially common in fast-developing countries. As an important part of the urban rail transit system, metro stations have attracted significant attention from both the metro system managers and researchers. They are most concerned 
about how to ensure the normal operation of the metro station and the evacuation of the crowd in emergency conditions.

According to the previous statistics of historic accidents, fire is one of the biggest and serious threats to metro systems, with the metro stations included [1]. Once a fire breaks out in a metro station, the high temperature, toxic gas, and smoke will not only affect the structure of the station but also may cause a significant loss of life [2]. Death is usually caused by poisoning or hypoxia from smoke and toxic gases produced by fire, and the smoke will also reduce the visibility along the evacuee's path, thus prolonging the exposure time to toxic gases [3].

The information of several significant fires that occurred in metro stations around the world is listed in Table 1. As can be seen from Table 1, fires that happen in metro stations can result in a large number of deaths and injuries. As for the reasons of the injuries and fatalities, exposure to smoke, toxic gas, and high temperature are the three main reasons according to the summary of historical fires $[9,10]$.

Previous research related to fires that happen in metro stations has been carried out by researchers from all around the world. By using a heptane pool (heat release rate 1.5 MW) located in a subscale tunnel model, Blanchard et al. [11] revealed the relationship between the heat flux received by the ceiling and the critical velocity. Numerical simulation and field test was carried out by Zhu et al. (2017) to estimate the effect of different ventilation conditions under fire conditions of a metro tunnel, and the position with most unfavorable smoke conditions for passenger's life safety was discussed as well [12]. Three fullscale model experiments were conducted in a unidirectional metro tunnel by Weng et al. [13]. By establishing a reduced-scale metro station model, Meng et al. [14] investigated the smoke temperature beneath the tunnel ceiling for a train on fire as it stopped at the side of a subway station platform. A reduced-scale subway station model was used by Giachetti et al. [15] to study smoke spreading, and the influence of the number of subway station openings and the ventilation volumetric flow rate were analyzed according to the data obtained by the model.

Due to the high costs of experimental tests, numerical modeling has also been used to study the fires that happen in metro stations. Computer software including Fire
Dynamic Simulator (FDS), Fluent, Consolidated Fire and Smoke Transport (CFAST), and AIRPAK have been widely used for fire simulation. By using FDS, metro station fire simulations were carried out by Meng, $\mathrm{N}$ and $\mathrm{Hu}$ et al to study the effectiveness of different ventilation modes under the condition of fire that happens in a train that is stopped in a subway station (2014) [16]. FDS software was adopted by Zhao et al. (2016) to study the effects of different ventilation modes on the smoke spreading in a subway station with a unique structure after fire breaks out [17]. Yuan et al. [18] came up with an optimization method for the ventilation condition of a subway side platform by using the software AIRPAK. Wang et al. [19] studied the smoke spread of a fire occurring on the subway platform by using software Fluent and FDS. In general, numerical simulation has become more and more popular for its low cost and efficiency.

As identified above, a lot of research related to the fire that happed in the metro station has been carried out. However, a comparison of fires that happen in metro stations with different structures and layouts has not been reported. Understanding how the toxic and harmful substances produced by fire spread in metro stations with different structures can be helpful for the structure design of metro stations to be constructed. Besides, fire simulation software has been widely used for research for its low cost and accuracy. Fire models based on metro stations with typical structures used in the metro system of Washington, D.C., and Guangzhou Metro are established by using PyroSim, a widely used fire simulation software. The spread characteristics of the toxic gases produced by the combustion will be compared and discussed. At last, the more appropriate structure for metro stations to be built is proposed when other factors like construction cost are also taken into account.

\subsection{Structures of Typical Metro Stations}

\subsection{Typical Station Structure of Washington, D.C., Metro System}

The metro system of Washington, D.C., was opened to the public in 1976. The metro system of Washington, D.C.,
Table 1 Significant fires in metro stations around the world

\begin{tabular}{lllrr}
\hline Date & Location & Causes & \multicolumn{2}{c}{ Results } \\
\cline { 3 - 5 } & & & Death & Injuries \\
\hline Nov 23, 1984 & Oxford Circus, London [4] & Smoking materials & 0 & 14 \\
Nov 18, 1987 & King's Cross, London [5] & Unburned match & 31 & 100 \\
Oct 28, 1995 & Baku metro, Azerbaijan [6] & Electrical malfunction & 289 & 265 \\
Feb 18, 2003 & Daegu, South Korea [7] & Arson & 192 & 148 \\
Feb 10, 2017 & Tsim Sha Tsui, Hong Kong [8] & Arson & 0 & 19 \\
\hline
\end{tabular}


now has 91 stations, which are connected by 6 lines with a total length of $188.3 \mathrm{~km}$. Most metro stations in the suburban area of Washington, D.C., are elevated stations, while underground stations are more common in urban areas. Figure 1 shows a common structure widely adopted in the metro system of Washington, D.C. The underground stations of the metro system of Washington, D.C. usually have a high and arched ceiling, i.e., a "high-dome" structure, which is quite different from the common structure of metro stations in other cities. The escalator and staircase at the two ends of the platform are used to connect the platform with a smaller terrace, where tickets can be purchased. The terrace acts as the station hall of other metro systems, but it is smaller than a regular station hall. Most underground metro stations in Washington, D.C., use the "island-style" platform as shown in Figure 1.

\subsection{Typical Station Structure of Guangzhou Metro System}

The first rail line of Guangzhou Metro began to operate on 28 June, 1997. Guangzhou Metro already has 14 rail lines with a total length of $478 \mathrm{~km}$ after developing for more than 20 years. There are 257 metro stations connected by these 14 rail lines. Just like stations in Washington, D.C., most metro stations located in the urban area of Guangzhou are underground stations. The "two-layer" structure shown in Figure 2 is widely used for underground metro stations in Guangzhou.

As shown in Figure 2, metro stations with "two-layer" structures are composed of two layers; they are the station hall layer and the platform layer. For underground metro stations, the station hall layer is usually the first layer underground, and the station hall layer is connected with ground/streets by exit/entrance. The platform layer is

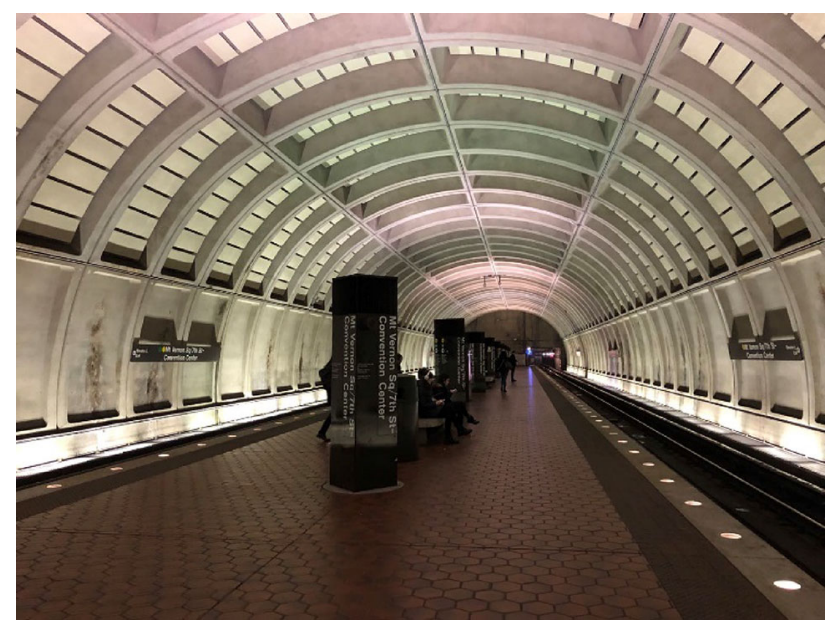

Figure 1 "High-dome" structure widely used in stations of the metro system of Washington, D.C.

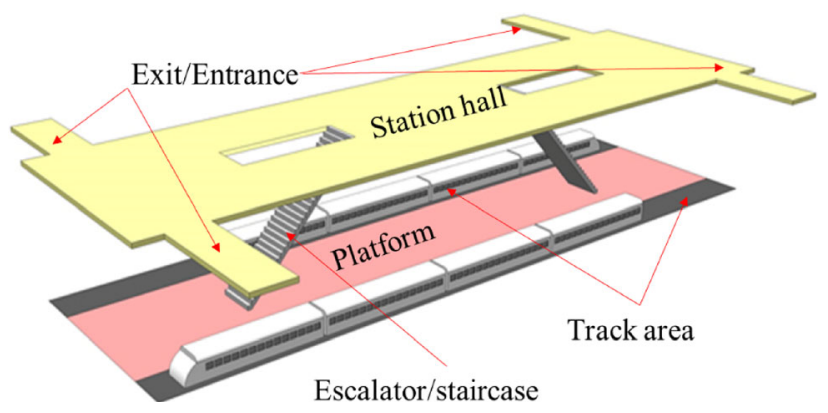

Figure 2 "Two-layer structures" most widely adopted in underground stations in Guangzhou

below the station hall layer, and it is typically the second layer underground. Usually, the station hall layer and platform layer are connected by several escalators, elevators and/or staircases.

The typical platform layer for an underground metro station in Guangzhou is shown in Figure 3. The "islandstyle" platform is most common in the stations of Guangzhou metro, and the platform screen doors (PSD) are installed on both edges of the platform. Ventilation systems are installed on the ceiling of the platform layer, which is used for daily air renewal and smokes exhaust under fire conditions. As shown in Figure 3, this kind of metro station has a "flat ceiling", as shown in Figure 3, which is quite different from the "high-dome" structure widely used in Washington, D.C.

\section{Metro Station Fire Simulation Model}

\subsection{Simulation Software}

FDS has been used by researchers to study fires in a variety of buildings and occupancies, including high-rise buildings [20], cinemas [21], high-speed trains [22], and metro stations [23]. PyroSim is a simulation software for fire

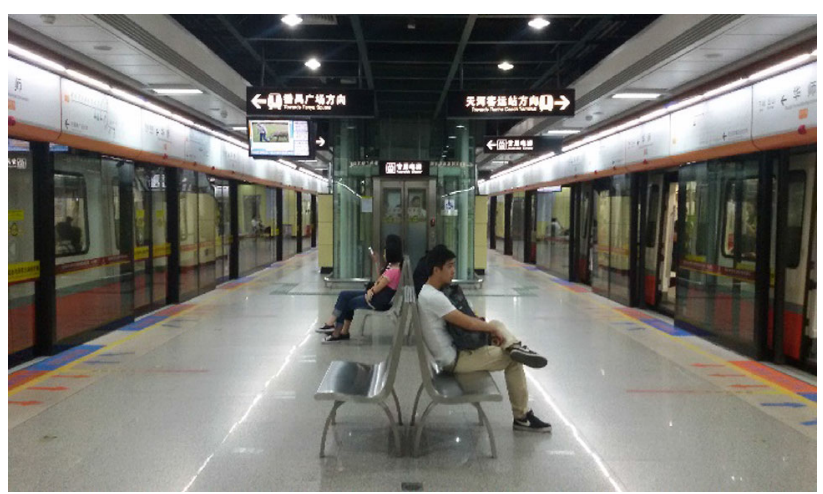

Figure 3 Typical metro station with "flat ceiling" in Guangzhou (platform layer) 
dynamics with human-computer interaction and a graphical user interface. The software can quickly and conveniently build models and directly present the calculated results in graphic and other visual forms, which has been widely used. Thus, PyroSim was selected to establish fire models for typical metro stations of Washington, D.C., and Guangzhou in this article.

\subsection{Dimension and Simulation Models of the two Typical Metro Stations}

When establishing the fire model of a typical Guangzhou Metro station, the "flat ceiling" structure shown in Figure 3 was selected. The dimension of the Guangzhou Metro station used to establish the model is shown in Figure 4. The platform of this station is an "island-style" platform with a width of $12 \mathrm{~m}$. There are two 3.3-m-wide track areas on both sides of the platform. The platform layer is $120 \mathrm{~m}$ in length, $4.7 \mathrm{~m}$ in height, $18.6 \mathrm{~m}$ in width, and $120 \mathrm{~m}$ in length, respectively. Platform screening doors (PSD) are installed on the two edges of the platform.

The dimension of the typical station in Washington, D.C., used to establish the fire simulation model is illustrated in Figure 5. As shown in Figure 5, the platform is "island-style", and there are track areas with $3.3 \mathrm{~m}$ width on both sides of the platform. The platform is $0.98 \mathrm{~m}$ in height, $12 \mathrm{~m}$ in width, and $120 \mathrm{~m}$ in length. The distance between the surface of the platform (ground) and the highest point of the tunnel is $8.45 \mathrm{~m}$. It means the clearance of the platform layer is $8.45 \mathrm{~m}$.

Table 2 shows the information about the mesh information of fire model established based on typical metro station of Guangzhou and Washington, D.C. These two models will be called Guangzhou model and Washington model for short in the latter part of this article. To ensure the accuracy of the simulation results, different cell sizes were applied when meshing the models and the results obtained from these models are compared. When some mesh sizes are adopted, the model cannot complete the calculation, i.e., non-convergence problem, this proves that

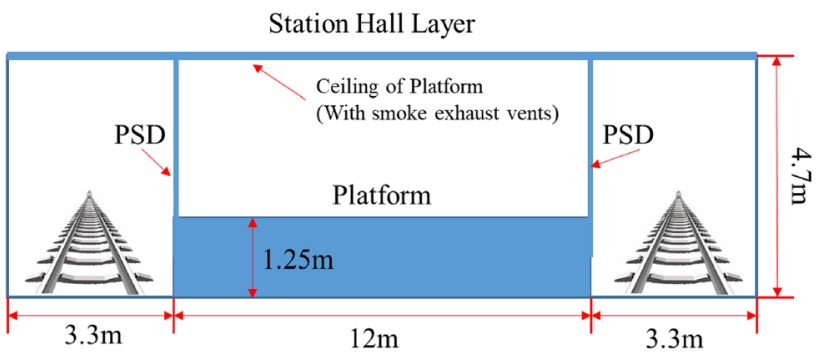

Figure 4 The dimension of the typical metro station in Guangzhou used to establish the fire simulation model (cross section)

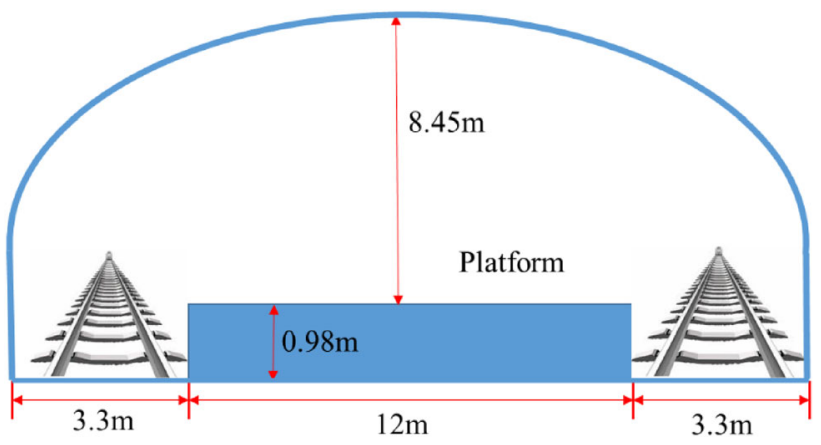

Figure 5 The dimension of the fire simulation model based on the typical station in the metro system of Washington, D.C. (cross section)

these kinds of mesh sizes are inadaptable. Also, finer meshes will lead to a long calculation time.

Reasonable mesh size should ensure the accuracy of the calculation results and the calculation time should not be too long. After multiple computational attempts and comparisons, the author found reasonable results can be obtained by applying cell size presented in Table 2 to the Guangzhou model and the Washington model, and the calculation time is less than $10 \mathrm{~h}$. Besides, after the models have been meshed, the Mesh Alignment Test Function provided by PyroSim is applied for the mesh verification to ensure the models are well meshed.

\subsection{Factors of Fire}

Fire sources with different materials, different fuels, and different factors such as heat release rate will have a significant impact on the development of fire and the generation of smoke and poisonous gases. When establishing a fire model, it's very important to determine the right fuel, material, and heat release rate for the fire source to be used in the fire scenario. According to the reports, most historical fires that happened in metro stations are caused by luggage or other items, for flame-resistant material are mandatorily used for the station decoration and all other equipment to be used in a metro station according to laws or regulations [24].

The heat release rate of fire that happened in crowded places ranges from 2.0 to $2.5 \mathrm{MW}$ [25]. Thus, fires with a heat release rate of $2.5 \mathrm{MW}$ which is considered as the most unfavorable condition are set in both the Guangzhou metro station model and the Washington metro station model.

After the heat release rate of the fire source is determined, the growth model is to be determined. According to the report of Gunnar Heskestad et al. (1989), the heat release rate will increase with time during the first stage after the fire begins. The growth of heat release rate in this stage can be illustrated by Eq. (1) [26]. 
Table 2 Mesh information of the two typical stations' fire dynamic simulation models

\begin{tabular}{lllll}
\hline Model & Mesh boundary length $(\mathrm{m})$ & Division method & Number of cells & Cell size \\
\hline Guangzhou model & x: $120 \mathrm{y}: 18.6 \mathrm{z:}: 4.7$ & Uniform & 411,264 & $0.2941(\mathrm{x}) \times 0.2952(\mathrm{y}) \times 0.2938(\mathrm{z})$ \\
Washington, D.C., model & x: $120 \mathrm{y}: 18.6 \mathrm{z}: 9.43$ & Uniform & 658,560 & $0.2143(\mathrm{x}) \times 0.3796(\mathrm{y}) \times 0.3813(\mathrm{z})$ \\
\hline
\end{tabular}

$\operatorname{HRR}=\alpha t^{2}$

In the equation, HRR is heat release rate, $\mathrm{kW} ; \alpha$, fire growth factor, $\mathrm{kW} / \mathrm{s}^{2} ; t$, time after the fire breaks out, $s$.

In this article, the $t^{2}$ model (shown in Figure 6) which is a non-steady fire growth mode is selected when establishing the fire models. After the heat release rate reaches the maximum value $\mathrm{HRR}_{\max }$, the growth of the heat release rate will then enter the second stage. The heat release rate will keep at the maximum value in the second state as shown in Figure 6.

Different fire sources have different growth rates of heat release rate, which can be illustrated by fire growth factor $\alpha$. The corresponding fire growth factor of different fire growth rates can be found in Table 3. The growth rates of the fire used in the Guangzhou model and Washington model are assumed to be ultra-fast, and the value of fire growth factor $\alpha$ will be 0.1878 according to Table 3 .

From what has been discussed above, the heat release rates of fires used in the models are $2.5 \mathrm{MW}$, with a fire growth factor of 0.1878 . By Eq. (1), the heat release rate of the fire in the Guangzhou model and Washington model will increase during the first $115 \mathrm{~s}$ after the fire begins and then enter the steady stage. In both fire models for Guangzhou Metro station and Washington, D.C., Metro station, materials of the fire source are set to be polyurethane, whose composition is listed in Table 4.

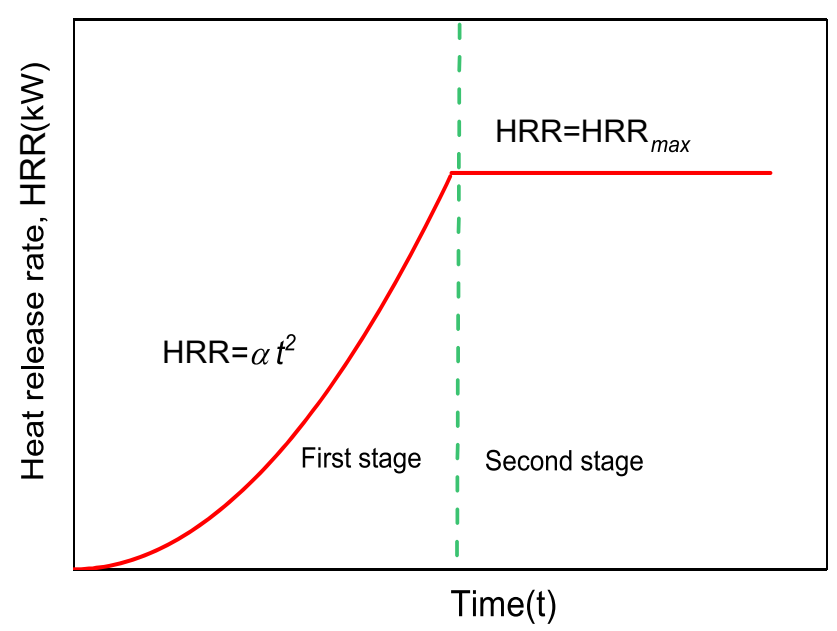

Figure 6 The increase of HRR in the $t^{2}$ fire model
Table 3 Different fire growth factors corresponding to the different fire growth rates

\begin{tabular}{lllll}
\hline Fire growth & Slow & Medium & Fast & Ultra-fast \\
\hline Growth factor $(\alpha)$ & 0.002931 & 0.01127 & 0.04689 & 0.1878 \\
\hline
\end{tabular}

\subsection{Fire Scenarios}

When a fire happens in a real metro station, the location of the fire is random and can be anywhere in the station. Fires in both the Guangzhou model and the Washington model are set to happen on the platform. As for the location of the fire, fires that happen in the center of the platform and at the end of the platform are considered when establishing fire models for Guangzhou and Washington, D.C., Metro stations. Figure 7 illustrates the fire locations on the platform of metro station models.

\subsection{Environmental Settings}

Both the Guangzhou model and Washington model are established based on their typical underground metro stations, and there is typically limited airflow in relatively confined spaces like underground metro stations. Thus, it is assumed that there is no airflow in the metro station of the Guangzhou model and Washington model. Also, the original temperature in the metro station of both models was set to be $20{ }^{\circ} \mathrm{C}$ for the stations are equipped with air conditioning systems. According to Jeon et al. (2011), the visibility in a metro station in a normal building is usually greater than $20 \mathrm{~m}$ when lighting is on and regarding evacuee's vision [27]. The maximum visibility on the platforms of both models is set at $30 \mathrm{~m}$ in the metro station of both models. For the models of the station in Guangzhou, the platform screening doors are set to be closed during the simulation calculation process.

\subsection{Established Model}

The established models based on typical metro stations in Guangzhou and Washington, D.C., are shown in Figures 8 and 9, respectively. The ceilings of the two models are fully or partially removed for a better view of the inner 
Table 4 The material composition of polyurethane used in fire models

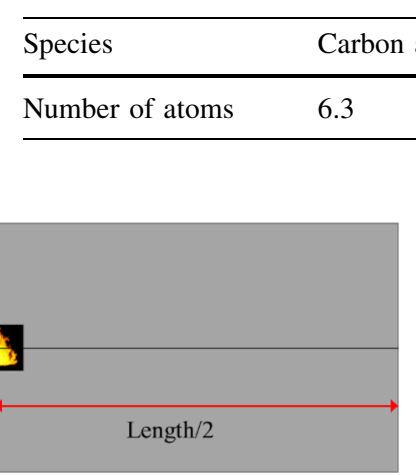

(a) fire in platform center

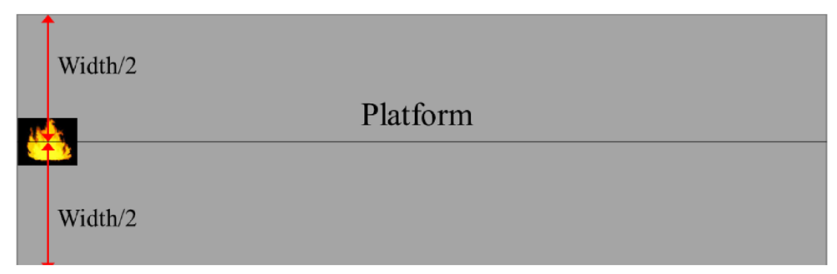

(b) fire at the end of the platform

Figure 7 Locations of the fires on the platform of Guangzhou model and Washington model

structure of the station. The fire source (marked as a red square) is located in the center of the platform.

The established model based on the typical structure of Washington, D.C., Metro station is the same as the model based on the typical structure of Guangzhou Metro station except for the platform ceiling, the former metro station model has a platform structure shown in Figures 1 and 5, in the shape of "high dome," while the Guangzhou model has a platform layer structure shown in Figures 3 and 4, in the shape of "flat ceiling".

\subsection{Location of the Monitoring Devices}

\subsubsection{Smoke Layer Height Detector}

Smoke layer height detectors are installed in the established models. The location of the smoke layer height detectors is shown in Figure 10. Eight smoke layer height detectors are installed at the same locations in the models based on the station of the metro system of Washington, D.C., and Guangzhou Metro station. The serial numbers of these eight smoke layer height detectors are shown in Figure 10. The smoke height change at these locations can be monitored and recorded during the entire simulation process.

\subsubsection{Thermocouples}

Eight thermocouples are installed $1.7 \mathrm{~m}$ high above the platform in both Guangzhou models and Washington models. The locations of these thermocouples are shown in Figure 11. The thermocouples provide data related to the temperature change throughout the simulation period.

\subsubsection{Temperature and Visibility Slices}

Slices in PyroSim allow contours of temperature and visibility to be exported as outputs of the simulation. To make a comparison between the models of the different metro stations, temperature and visibility slices were added to both models. The temperature slices were installed at the safety smoke heights of the two models, and they are $1.945 \mathrm{~m}$ in the Guangzhou model and $1.8 \mathrm{~m}$ in the Washington, D.C., model. The visibility slices were installed $1.6 \mathrm{~m}$ above the floor of the platform in both models, for the average height of women in most countries is around $1.6 \mathrm{~m}$ according to Wikipedia [28].

\section{Results and Discussion}

\subsection{Smoke Height Change}

In the event of a fire occurring in a relatively enclosed space, the smoke generated by the fire will first accumulate at the top of the space and gradually decrease with time [29]. Passengers can be safely evacuated only under the condition that the smoke height is always above the safety height during the whole evacuation process. Otherwise, passengers in the evacuation process will be more or less affected by the smoke. Equation (2) proposed by Shi et al. (2008) can be used for the calculation of the safety height of smoke [30].

Hs $=1.6+0.1 H$

In the equation, $\mathrm{Hs}$ is safety height of smoke $(\mathrm{m}) . H$, interior space height of the building where fire happens, $\mathrm{m}$, for example, the height of a classroom or hall.

The height of the platform layer (clearances) in the Guangzhou models is $3.45 \mathrm{~m}$, so the safety height of smoke on each platform is $1.945 \mathrm{~m}$ according to Eq. (2). However, the International Building Code (2018), which is widely adopted in the USA, suggests the smoke layer must not descend below $1.8 \mathrm{~m}$ above the highest walking surface [31]. Thus, the safety height of smoke for the metro station models of Washington, D.C is set as $1.8 \mathrm{~m}$.

Figures 12 and 13 illustrate the smoke height change during 0-360 s in the Guangzhou model and Washington 
Figure 8 The established model based on the typical metro station in Guangzhou (flat ceiling removed)

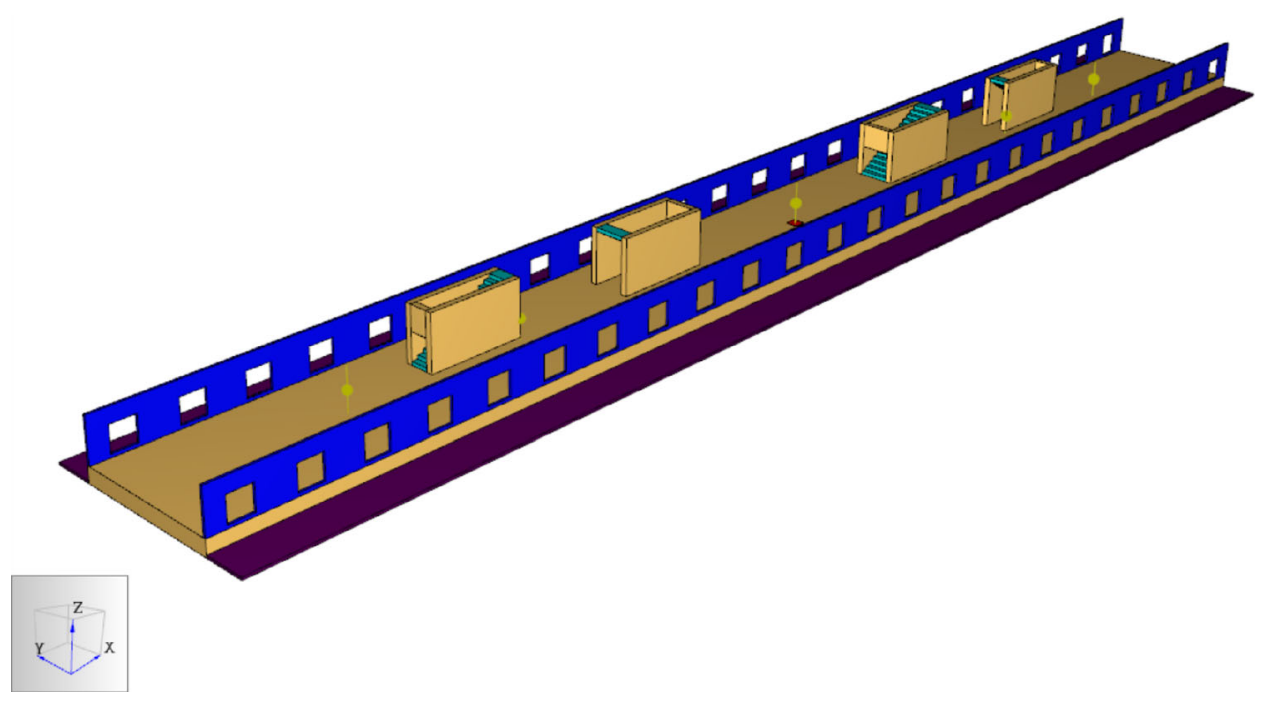

Figure 9 The established model based on the typical metro station in Washington, D.C. (high-dome ceiling partially removed)

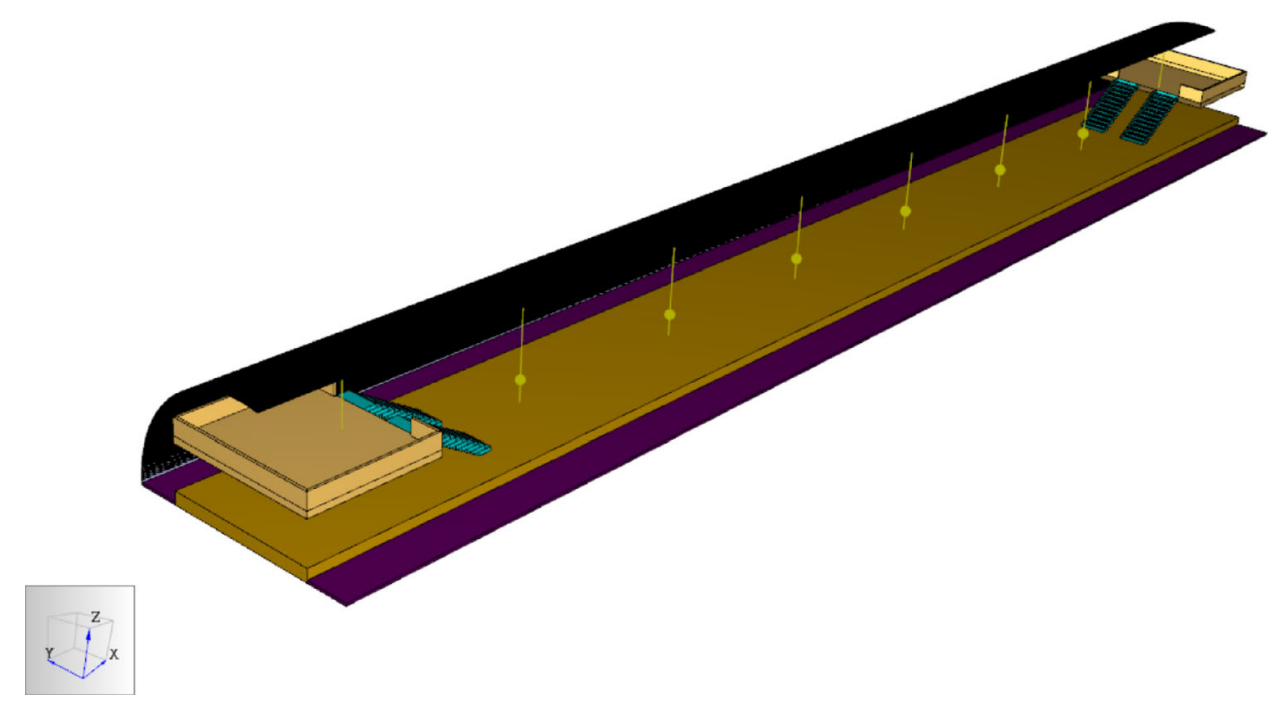

Figure 10 Locations of the two smoke layer height detectors (not to scale)

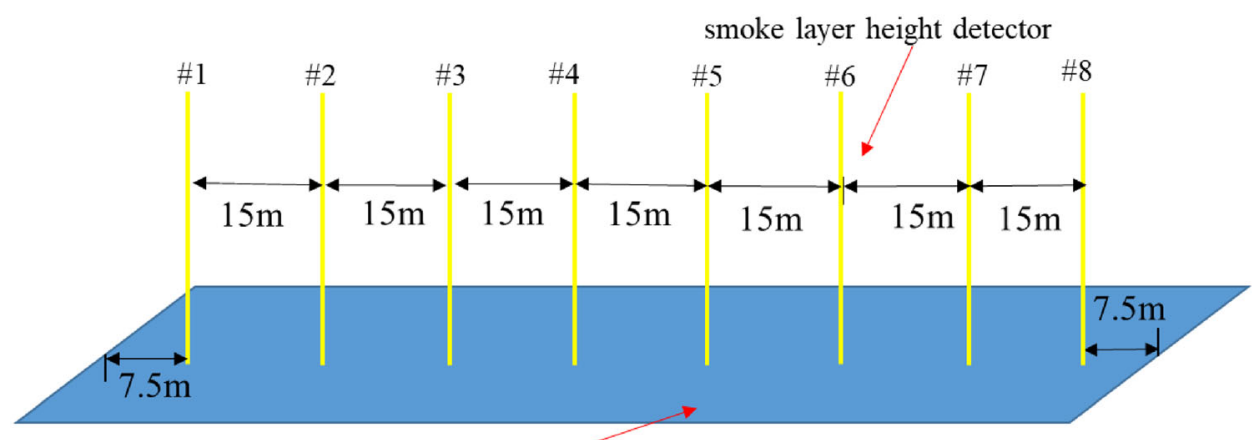

Floor of Platform

model, respectively. As shown in Figure 12a, b, the smoke height varies between 2.75 and $3.45 \mathrm{~m}$ when the fire location is in the platform center, while the smoke height varies between 2.55 and $3.45 \mathrm{~m}$ when the fire location is at the end of the platform. The lowest smoke height to the safe height of smoke $(1.95 \mathrm{~m})$ is about $0.8 \mathrm{~m}$ and $0.6 \mathrm{~m}$, respectively.

A similar result is observed for the model based on the typical Washington, D.C., Metro station. As shown in Figure 13, the lowest smoke heights are both around 
Figure 11 Locations of the thermocouples (not to scale)
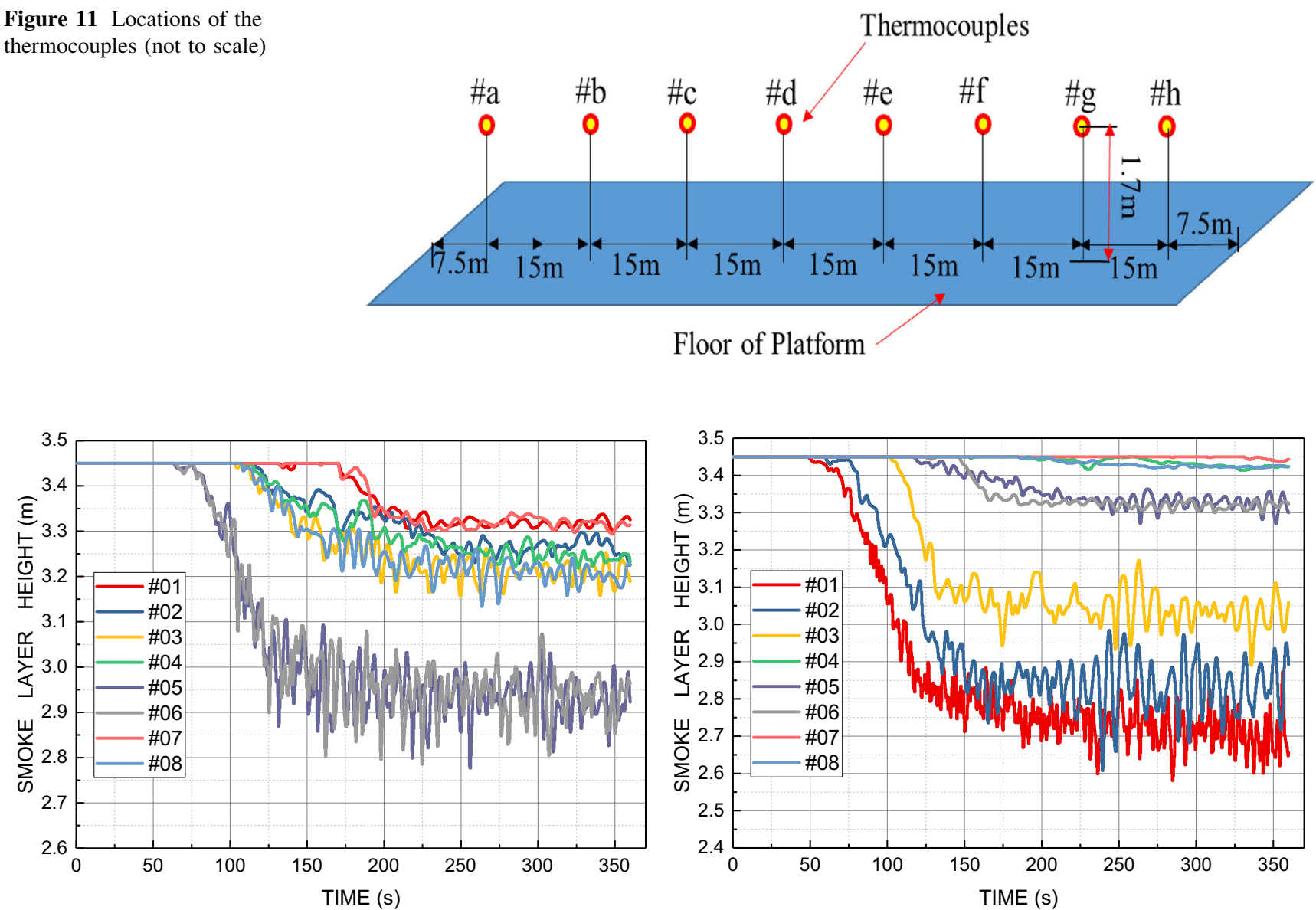

(a) fire in the platform center

Figure 12 Smoke height change of Guangzhou model

$7.85 \mathrm{~m}$ when the fire is located in the platform center and at the end of the platform. The lowest smoke height to safe height of smoke $1.8 \mathrm{~m}$ is about $6.15 \mathrm{~m}$ when the fire is on the platform center, while its $6.2 \mathrm{~m}$ when the fire is at the end of the platform.

It can be seen that when the same fire breaks out in metro stations of Guangzhou and Washington, D.C., it takes more time for the smoke height to drop below the safe smoke height in the Washington, D.C., station. This means passengers in Washington, D.C., Metro stations will have more time to escape before the smoke height becomes too low under the same fire condition. These simulations did not include the operation of the smoke exhaust system which could result in different available safe evacuation times. To make the smoke height drop slower in the typical metro station in Guangzhou, more powerful smoke exhaust equipment should be installed.

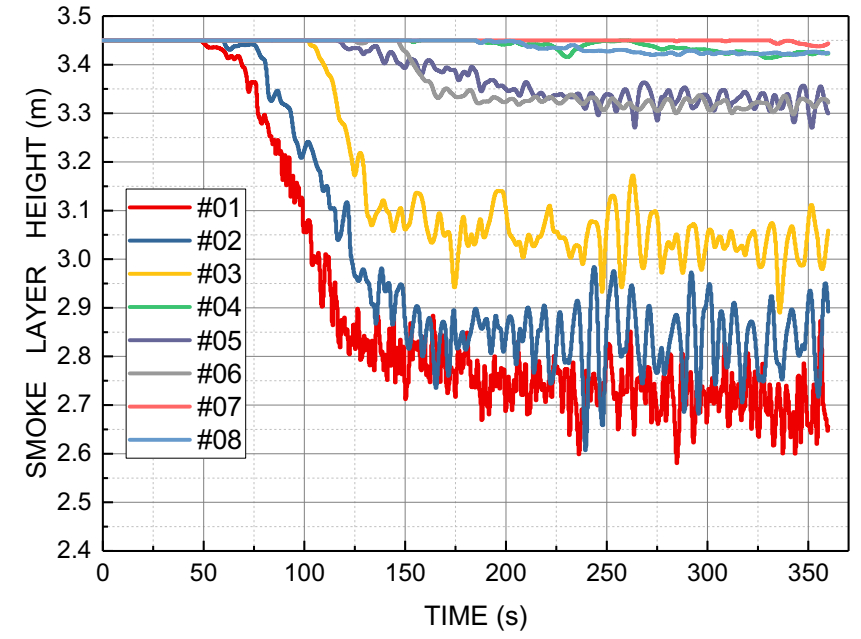

(b) fire at the end of the platform

\subsection{Temperature Change}

The monitored temperature change of the thermocouples during 0-360 s in the Guangzhou model and Washington model is shown in Figures 14 and 15, respectively. The highest temperature monitored in the Guangzhou model is about $43{ }^{\circ} \mathrm{C}$ when the fire is located in the platform center, while the highest temperature is about $49{ }^{\circ} \mathrm{C}$ when the fire is located at the end of the platform. It means the maximum temperature increment monitored is $23-29{ }^{\circ} \mathrm{C}$ in the set scenario of the Guangzhou model.

As can be seen from Figure 15, the temperature of the thermocouples in the Washington model shows a rising trend during the whole calculation process. The highest temperature monitored in the condition fire locates in the platform center is about $29^{\circ} \mathrm{C}$, while the highest temperature is about $28.5^{\circ} \mathrm{C}$ when the fire is located on the end of the platform. The maximum temperature increment monitored is $8.5-9{ }^{\circ} \mathrm{C}$, which is much lower than that in the Guangzhou model. 


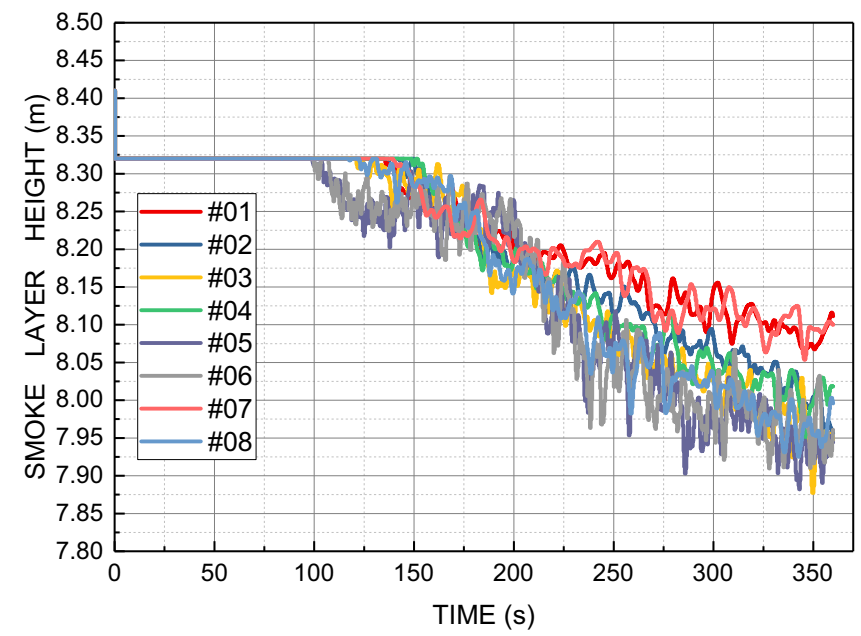

(a) fire in the platform center

Figure 13 Smoke height change of Washington model

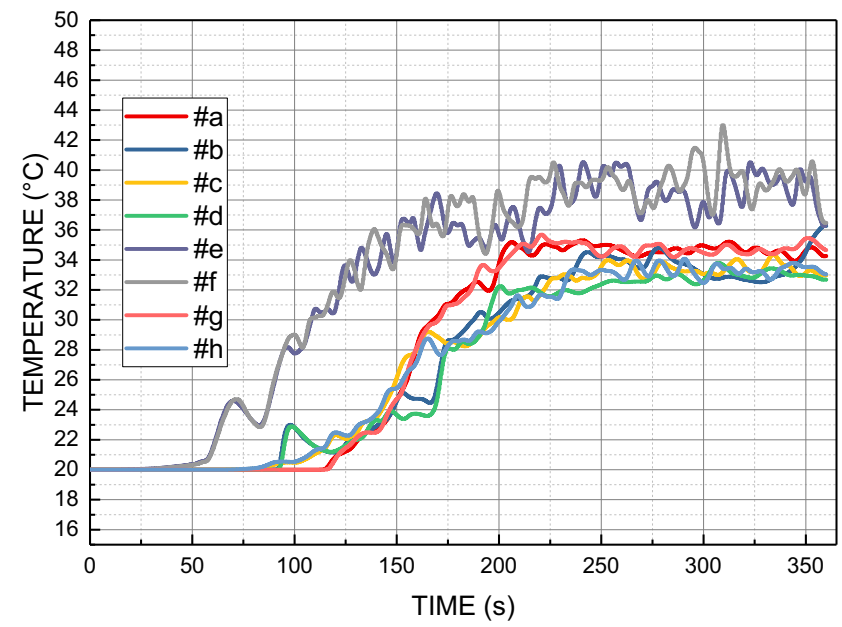

(a) fire in the platform center

Figure 14 The temperature change of the Guangzhou model

Figure 16 illustrates the temperature on the slices $1.8 \mathrm{~m}$ above the platform floor in the Guangzhou model at the time $360 \mathrm{~s}$ after the fire begins. When the fire is located in the platform center of Guangzhou model, the highest temperature $40{ }^{\circ} \mathrm{C}$ appears in the areas of the platform center and the two ends of the platform. When the fire is located at the end of the platform, the highest temperature close to $50{ }^{\circ} \mathrm{C}$ appears at the end of the platform where the fire is located.

Figure 17 shows the temperature on the slice $1.945 \mathrm{~m}$ above the platform floor at $360 \mathrm{~s}$ after the fire breaks out in the station of Washington model. It shows the temperature in most areas of the platform is approximately $22-28{ }^{\circ} \mathrm{C}$ when the fire is located in the platform center, while the

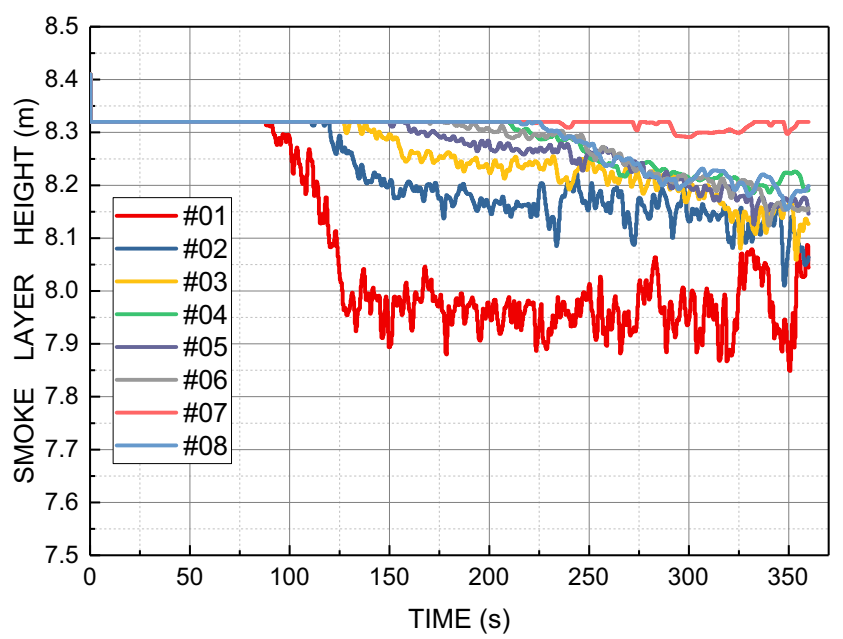

(b) fire at the end of the platform

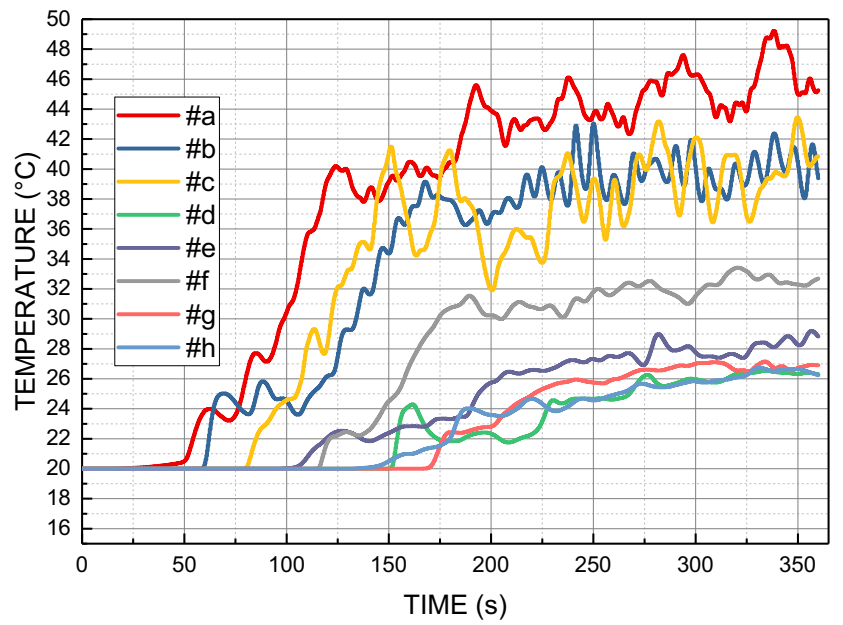

(b) fire at the end of the platform

temperature ranges between 23 and $30{ }^{\circ} \mathrm{C}$ when the fire is located at the end of the platform.

In general, the temperature in the station of Guangzhou model is much higher than that in the station of Washington model. This is because the room of the station of Washington model is much bigger than the station of Guangzhou model, it will need more heat to raise the temperature. As discussed before, lower temperatures will benefit the evacuation of passengers. It indicates that the metro station with a "high-dome" structure like the typical station in Washington can provide a safer evacuation environment when fires with the same scale break out. 


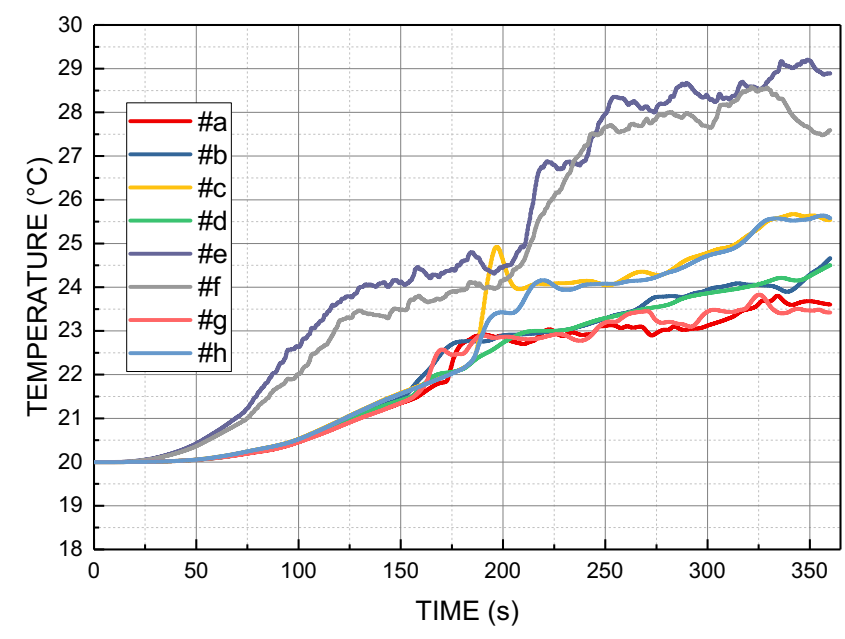

(a) fire in the platform center

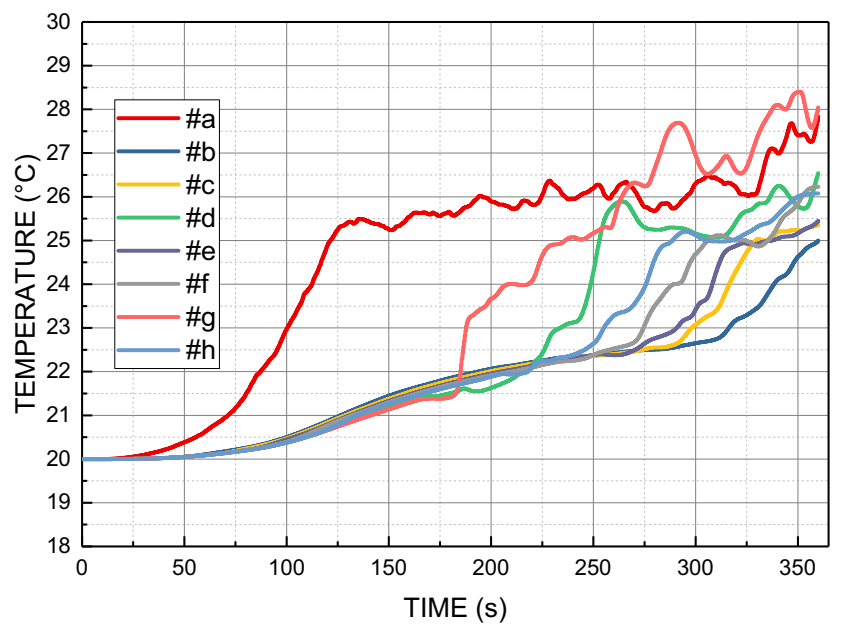

(b) fire at the end of the platform

Figure 15 The temperature change of the Washington model

Figure 16 Temperature slice

$1.8 \mathrm{~m}$ above the platform floor at $360 \mathrm{~s}$ of Guangzhou model (unit: ${ }^{\circ} \mathrm{C}$ )

\section{다 1015}

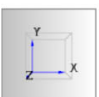

(a) fire in the platform center

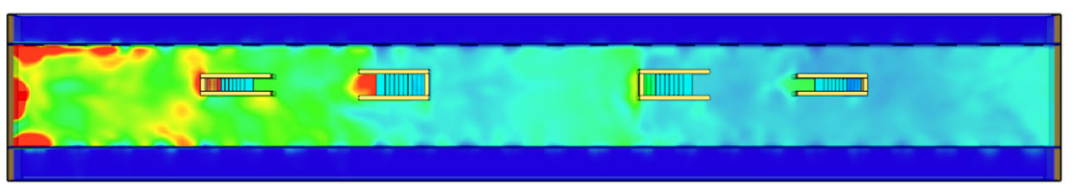


Figure 17 Temperature slice $1.945 \mathrm{~m}$ above the platform floor at $360 \mathrm{~s}$ of Washington model (unit: ${ }^{\circ} \mathrm{C}$ )

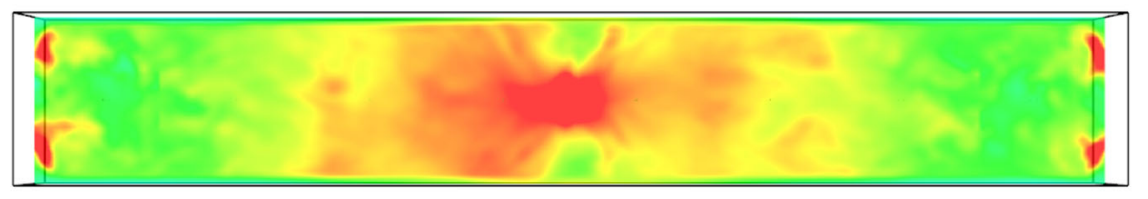

(a) fire in the platform center

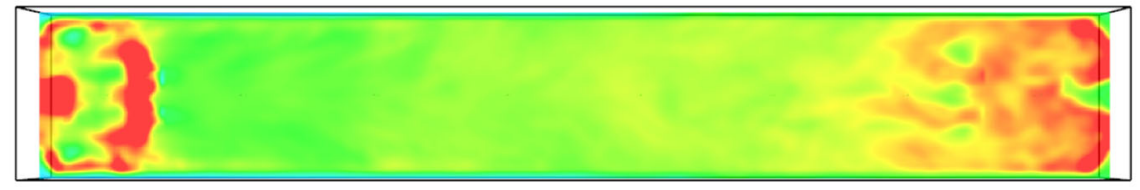

(b) fire at the end of the platform

\subsection{Visibility Change}

To ensure that evacuation routes can be seen under fire conditions, evacuation guide signs are typically installed in metro stations. In the event of a fire, the visibility in a metro station will be reduced by smoke. According to the Chinese Code for the Design of Metro System (GB 50157-2013), visibility of $10 \mathrm{~m}$ should be guaranteed during a fire that happens in a metro station. Figure 18 and Figure 19 illustrate the visibility on the slices $1.6 \mathrm{~m}$ above the platform floor at $180 \mathrm{~s}$ and $360 \mathrm{~s}$ after fire breaks out in the Guangzhou model.

Figure 18 shows that when the fire breaks out in the platform center or at the end of the platform, the visibilities $1.6 \mathrm{~m}$ above the two sides of the platform floor at $180 \mathrm{~s}$ are both $1.0-10 \mathrm{~m}$, which is well below the requirement of $10 \mathrm{~m}$ visibility. It can be seen from Figure 18a that the visibility at the two ends of the platform is much lower than the visibility in the center area. This is caused by the "ceiling effect", the smoke will gather at the ceiling first and generally spread in the direction to the two ends of the platform after the smoke reaches the two ends of the platform, and more smoke will accumulate at the area above the end of the platform, thus making the visibility at the two ends of the platform very low, while when the fire is located at the end of the platform, the visibility is lower in the part of the platform which is close to the fire, as shown in Figure 18b.

As shown in Figure 19, the visibilities of all areas $1.6 \mathrm{~m}$ above the platform at $360 \mathrm{~s}$ after fire breaks out are approximately $1.0 \mathrm{~m}$ no matter the fire is located in the platform center or at the ends of the platform in the Guangzhou model. 
Figure 18. Visibility slice

$1.6 \mathrm{~m}$ above the platform floor at $180 \mathrm{~s}$ of Guangzhou model

(unit: m)
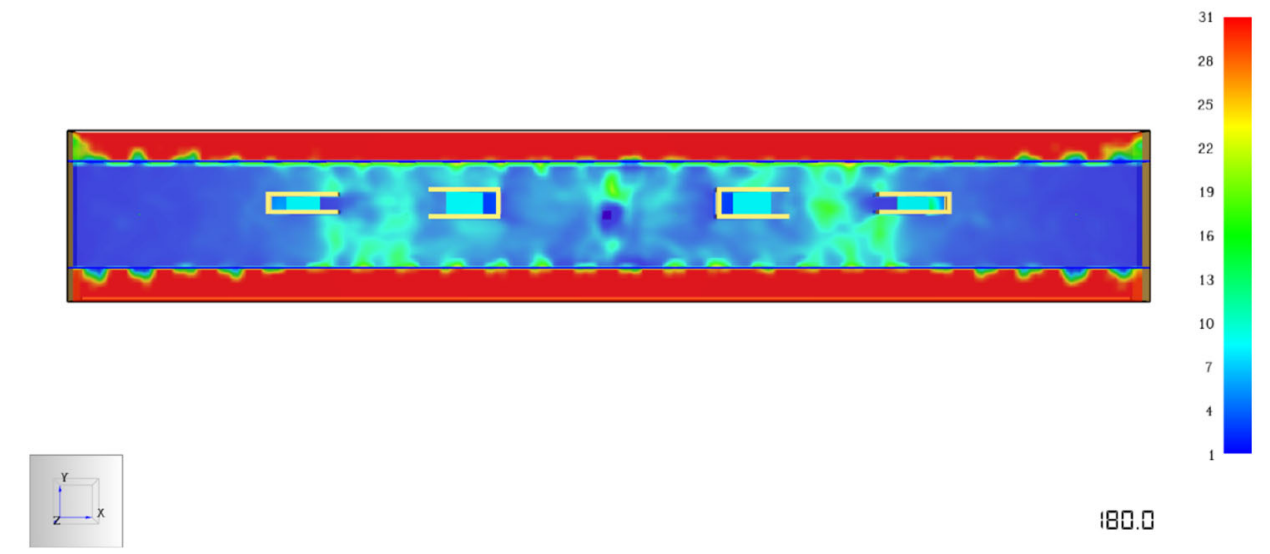

180.5

(a) fire in the platform center

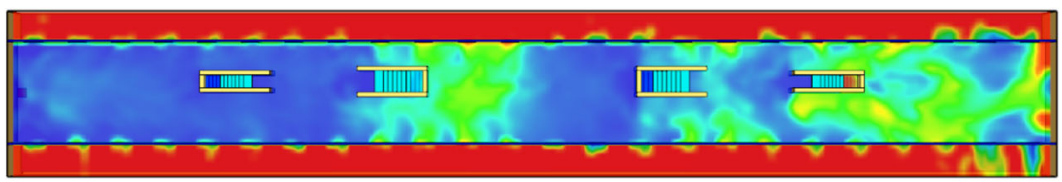

(b) fire at the end of the platform

Figures 20 and 21 show the visibility on the slices $1.6 \mathrm{~m}$ above the platform floor $180 \mathrm{~s}$ and $360 \mathrm{~s}$ after the fire starts of the Washington, D.C., model. Figure 20 shows the visibility at the height $1.6 \mathrm{~m}$ above the platform at $180 \mathrm{~s}$ is about $29 \mathrm{~m}$ in most areas of the platform when the fire is located in the platform center, while it is about $28.5 \mathrm{~m}$ when the fire is located at the end of the platform.

Figure 21 shows the visibility $1.6 \mathrm{~m}$ above the platform floor $360 \mathrm{~s}$ after the fire breaks out. Most areas of the platform have visibility of approximately $4-14 \mathrm{~m}$ as shown in Figure 21a when the fire is located in the platform center. When the fire is located at the end of the platform, the visibility at the platform in most areas is $1.5-13.5 \mathrm{~m}$ except the areas close to the fire.

The visibility decreased slower in the model based on the Washington, D.C., Metro station. At $180 \mathrm{~s}$ after the fire starts, the visibility in most areas of the Guangzhou model is among 1.0-10 m, while the visibility in most areas of the Washington, D.C., model is around $29 \mathrm{~m}$ or $28.5 \mathrm{~m}$ depending on the fire location. At $360 \mathrm{~s}$ after fire breaks out, the visibility in most areas of the Guangzhou model is quite low, approximately $1 \mathrm{~m}$ in most areas, while the visibility in most areas of the Washington, D.C., model is approximately $4.0-14 \mathrm{~m}$ or $1.5-13.5 \mathrm{~m}$ which depends on 
Figure 19 Visibility slice

$1.6 \mathrm{~m}$ above the platform floor at $360 \mathrm{~s}$ of Guangzhou model

(unit: m)
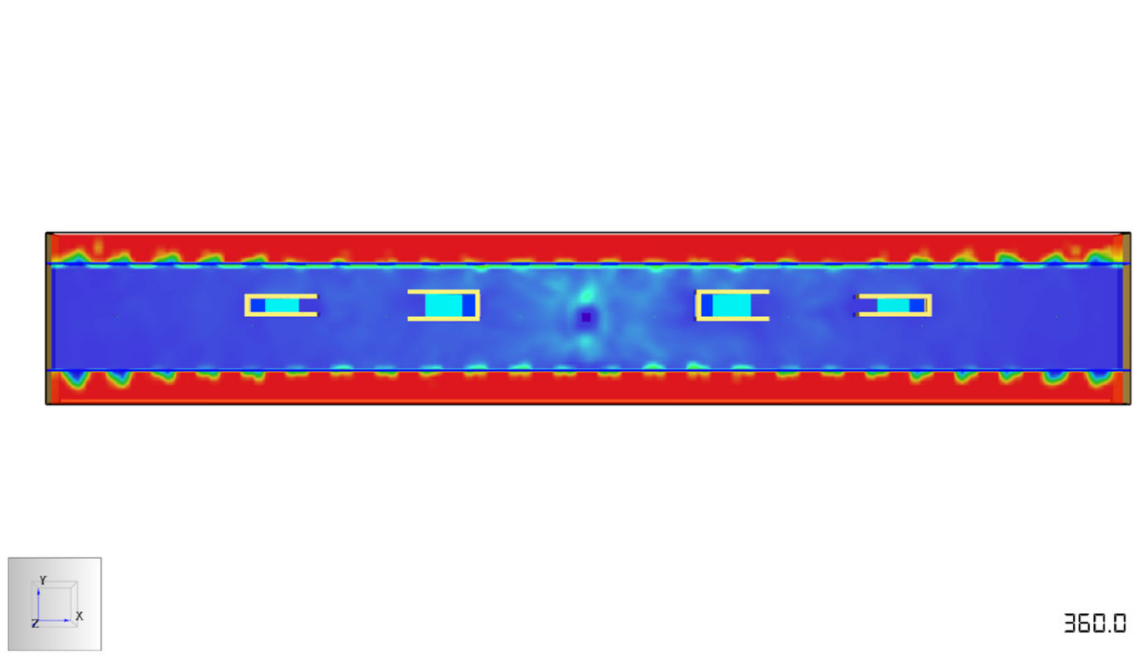

(a) fire in the platform center

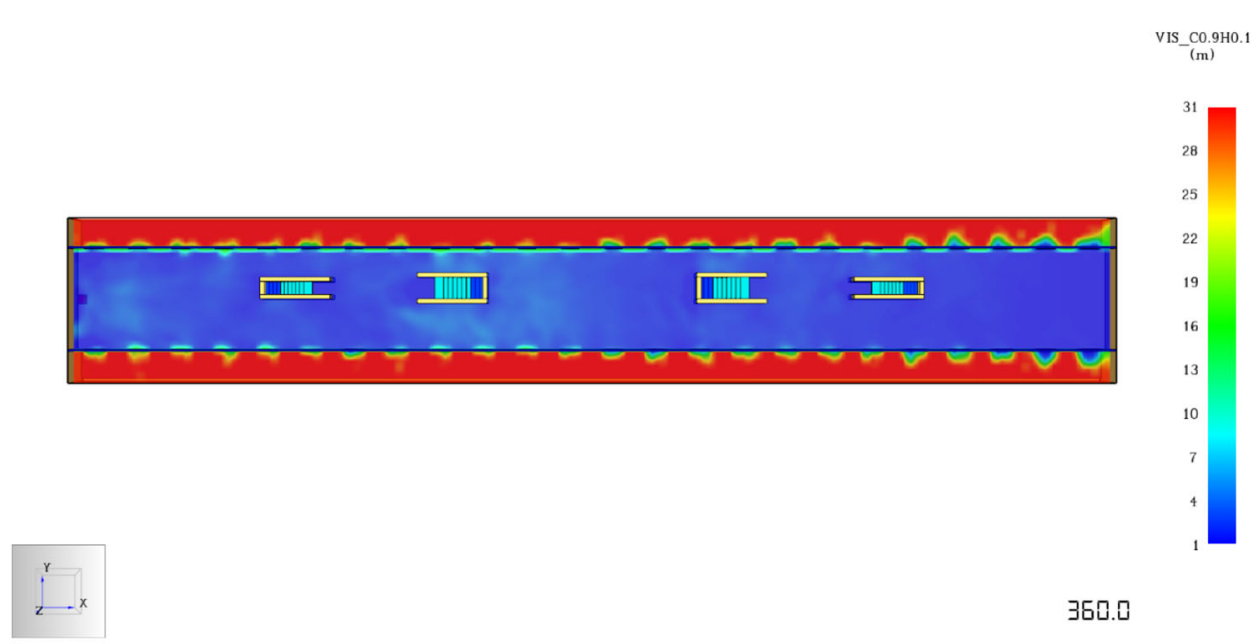

(b) fire at the end of the platform

the fire location. Thus, passengers in the station with higher clearance can have more available time to evacuate before conditions become untenable.

\section{Conclusions}

Simulation models of fires on the platform of metro stations in Guangzhou and Washington, D.C., were studied. The two metro stations used for the scenarios have typical structures which are widely used in the metro system of Guangzhou and Washington, D.C. Results listed below are obtained by the simulation analysis:
1. The lowest smoke heights monitored in the Guangzhou model are $0.6 \mathrm{~m}$ (fire at the platform end) and $0.8 \mathrm{~m}$ (fire in the platform center) above the safe smoke height at $360 \mathrm{~s}$ after the fire breaks out, while it is $6.15 \mathrm{~m}$ (fire in the platform center) and $6.2 \mathrm{~m}$ (fire at the platform end) above the smoke height in the Washington model. It indicates that the time required for the smoke layer to descend in the lower ceiling case was nonlinear to the difference in ceiling height; the smoke layer descended faster than for the high ceiling condition.

2. The temperature in the platform layer of the Guangzhou model increases more quickly than that in the 
Figure 20 Visibility slice

$1.6 \mathrm{~m}$ above the platform floor at $180 \mathrm{~s}$ of Washington model (unit: $\mathrm{m}$ )

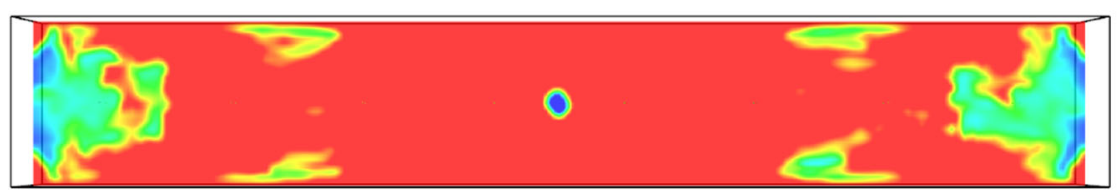

11.5

${ }_{9}^{9}$

180.8

(a) fire in the platform center

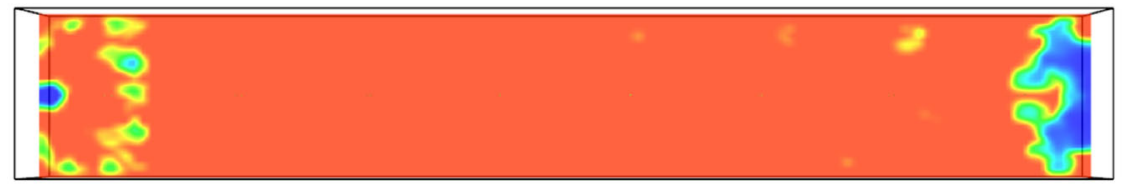

VIS_C $C .9 H 0.1$

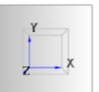

180.0

(b) fire at the end of the platform

Washington, D.C., model after fire breaks out. The temperature increment in the Guangzhou model is $23{ }^{\circ} \mathrm{C}$ (fire in the platform center) to $29{ }^{\circ} \mathrm{C}$ (fire at the platform end) at $360 \mathrm{~s}$ after the fire breaks out, while the temperature increment in the same period in the Washington model is $8.5^{\circ} \mathrm{C}$ (fire at the platform end) to $9{ }^{\circ} \mathrm{C}$ (fire in the platform center).

3. In the same fire condition, the visibility decreases slower in the Washington, D.C., model. The visibility of most areas on the platform of the Guangzhou model is about $1 \mathrm{~m}$ no matter the fire is in the platform center or at the platform end at $360 \mathrm{~s}$ after the fire begins, while in the Washington model, the visibility is
4-14 $\mathrm{m}$ (fire at the platform end) to $1.5-13.5 \mathrm{~m}$ (fire in the platform center) at the same moment.

As discussed above, the environment is worse when the fire happens at the end of the platform than that when the fire happens in the platform center of the Guangzhou model, while the fire location has fewer impacts on the smoke height, temperature, and visibility in the Washington model. A metro station with higher clearance can provide a safer evacuation environment when a fire breaks out. While the metro station with a higher ceiling provides more available safe egress time, higher ceilings may not always be the best option. Underground stations with 
Figure 21 Visibility slice

$1.6 \mathrm{~m}$ above the platform floor at $360 \mathrm{~s}$ of Washington model

(unit: $\mathrm{m}$ )
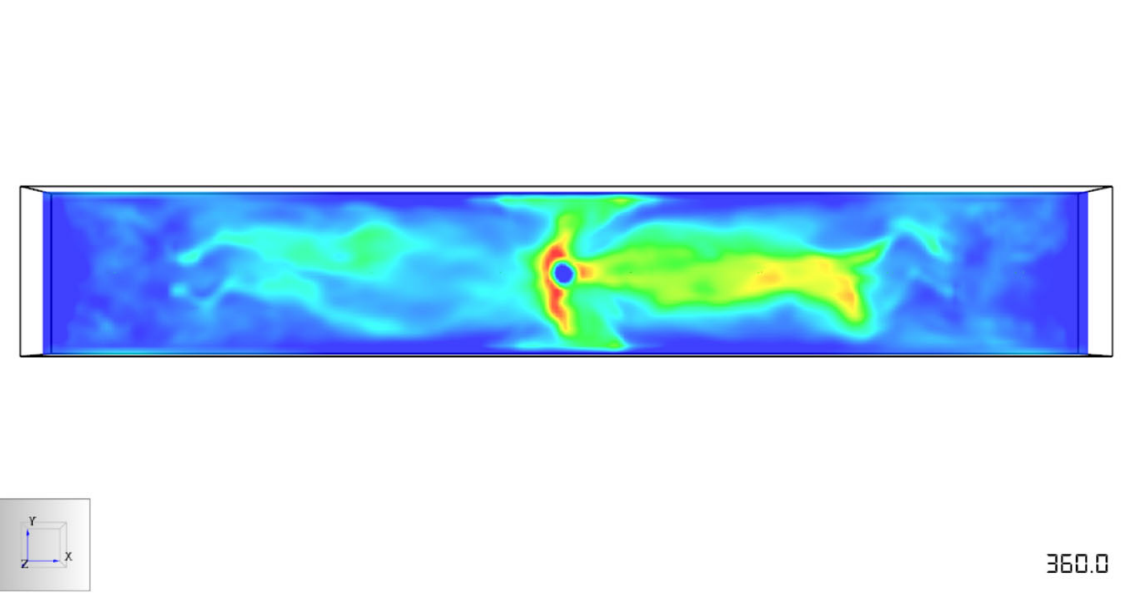

\section{(a) fire in the platform center}

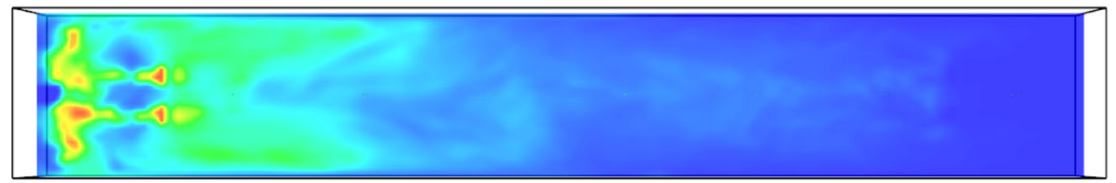

\section{(b) fire at the end of the platform}

higher clearances will require higher construction costs. The right construction structure of a metro station should also consider the cost, the geology, and the other related factors. If it is not feasible to build underground stations with higher clearance, other auxiliary measures, such as smoke exhaust systems, should be added to prolong the evacuation time of passengers.

\section{Declarations}

Conflict of interest The author declares that no conflict of interest exists in the submission of this manuscript, and manuscript is approved by all authors for publication. The author would like to declare that the work described was original research that has not been published previously, and not under consideration for publication elsewhere, in whole or in part. The data used in the paper are all available from the corresponding author upon reasonable request; the email of the corresponding author is hengyu126@yahoo.com. Besides, the author would like to thank Dr. Bryan Lawrence Hoskins of Oklahoma State University for his help with English editing.

Open Access This article is licensed under a Creative Commons Attribution 4.0 International License, which permits use, sharing, adaptation, distribution and reproduction in any medium or format, as long as you give appropriate credit to the original author(s) and the source, provide a link to the Creative Commons licence, and indicate if changes were made. The images or other third party material in this article are included in the article's Creative Commons licence, unless indicated otherwise in a credit line to the material. If material is not included in the article's Creative Commons licence and your intended use is not permitted by statutory regulation or exceeds the permitted use, you will need to obtain permission directly from the copyright holder. To view a copy of this licence, visit http://creativecommons. org/licenses/by/4.0/. 


\section{References}

1. Shi CL, Zhong MH, Nong XZ, He L, Shi JH, Feng GG (2012) Modeling and safety strategy of passenger evacuation in a metro station in China. Saf Sci 50:1319-1332

2. Zhao SZ et al (2018) A numerical study on smoke movement in a metro tunnel with a non-axisymmetric cross-section. Tunn Undergr Space Technol 73:187-202

3. Babrauskas V et al (1998) A methodology for obtaining and using toxic potency data for fire hazard analysis. Fire Saf J 31:345-358

4. London Regional Transport (1984) The fire on 23rd November 1984 at Oxford Circus station: enquiry report. Railways Archive. Retrieved 3 July 2013

5. Fennell D (1988) Investigation into the King's cross underground fire. HMSO Publications Centre, pp 15-19

6. Hedefalk J, Wahlstrom B, Rohlen P (1998) Lessons from the Baku subway fire. Proc Int Conf Safety in Road and Rail Tunnels, pp 15-28

7. Lee M, Hur N (2012) A detailed CFD simulation of the 2003 Daegu Metro station fire. Int J Air-Condit Refrig 20(03):1250014

8. Huang DY, Lo SM, Chen J, Fu ZJ, Zheng Y, Luo L, Zhuang YF, Cheng H, Yang L (2019) Mapping fire risk of passenger-carried fire load in metro system via floor field cellular automaton. Autom Constr 100:61-72

9. Babrauskas V, Gann RG, Levin BC, Paabo M, Harris RH, Peacock RD, Yusa S (1998) A methodology for obtaining and using toxic potency data for fire hazard analysis. Fire Saf J 31:345-358

10. Tong Y, Shi MH, Gong YF, He JP (2009) Full-scale experimental study on smoke flow in natural ventilation road tunnel fires with shafts. Tunn Undergr Space Technol 24:627-633

11. Blanchard E, Boulet P, Desanghere S, Cesmat E (2012) Experimental and numerical study of fire in a midscale test tunnel. Fire Saf J 47:18-31

12. Zhu P, Wei WZ, Mei J, Tu JF, Ding R (2017) Numerical simulation \& scene experiment of metro tunnel with crossover interval under fire conditions. Procedia Eng 205:87-94

13. Weng MC, Yu LX, Liu F, Nielsen PV (2014) Full-scale experiment and CFD simulation on smoke movement and smoke control in a metro tunnel with one opening portal. Tunn Undergr Space Technol 42:96-104

14. Meng N, Wang Q, Liu ZX, Li X, Yang H (2017) Smoke flow temperature beneath tunnel ceiling for train fire at subway station: reduced-scale experiments and correlations. Appl Therm Eng 115:995-1003

15. Giachetti B, Couton D, Plourde F (2017) Smoke spreading analyses in a subway fire scale model. Tunn Undergr Space Technol 70:233-239

16. Meng N, Hu LH, Wu L, Yang LZ, Zhu S, Chen LF, Tang W (2014) Numerical study on the optimization of smoke ventilation mode at the conjunction area between tunnel track and platform in emergency of a train fire at subway station. Tunn Undergr Space Technol 40:151-159

17. Zhao D, Jiang JC, Zhou R, Tong Y, Wu F, Shi LJ (2016) Numerical study on the optimization of smoke ventilation mode for interchange subway station fire. Int J Vent 15(1):79-93

18. Yuan FD, You SJ (2007) CFD simulation and optimization of the ventilation for subway side-platform. Tunn Undergr Space Technol 22:474-482

19. Wang BB (2011) Comparative research on FLUENT and FDS's numerical simulation of smoke spread in subway platform fire. Procedia Eng 26:1065-1075

20. Hadjisophocleous G, Jia Q (2019) Comparison of FDS prediction of smoke movement in a 10 -storey building with experimental data. Fire Technol 45:163-177

21. Glasa J, Valasek L, Weisenpacher P et al (2013) Cinema fire modelling by FDS. J Phys Conf Ser 410(1):1-4

22. Liang JH, Li X, Lin JH et al (2014) Analysis of EMU fire based on PyroSim. J Chongqing Univer Technol (Nat Sci Ed) 28(10):35-37 (in Chinese)

23. Meng N, Hu LH, Wu L, Yang LZ, Zhu S, Chen LF, Tang W (2014) Numerical study on the optimization of smoke ventilation mode at the conjunction area between tunnel track and platform in emergency of a train fire at subway station. Tunnell Underground Space Technol Incorp Trenchless Technol Res 40:151-159

24. Wu JS, Hu ZQ, Chen JY, Li Z (2018) Risk assessment of underground subway stations to fire disasters using Bayesian network. Sustainability 10(10):3810

25. Hansell GO, Morgan HP (1994) Design approaches for smoke control in atrium buildings. Buildings Research Establishing Report (BR-258), UK

26. Gunnar H, Michael AD (1989) The initial convective flow in fire. Fire Saf J 15(6):471-475

27. Jeon GY, Kim JY, Hong WH, Augenbroe G (2011) Evacuation performance of individuals in different visibility conditions. Build Environ 46(5):1094-1103

28. Wikipedia. Average Human Height by Country. https://en.wiki pedia.org/wiki/Average_human_height_by_country\#References.

29. Brewer R, Morrison L (2015) Fire alarm detection in high-ceiling rooms. In: 35th annual conference of the Canadian nuclear society. Canadian Nuclear Society, Saint John

30. Shi CL, Fu TR, He L, Zhong MH, Tu XW (2008) Train fire smoke control in deep buried island metro station. In: The 2008 international symposium on safety science and technology

31. International Code Council (2018) International Building Code. Falls Church, Virginia, United States 